\title{
INFLUENCE OF HEALTH SERVICE ACCEPTANCE VALUE TOWARD A PATIENT RELIANCE
}

\author{
Sri Sustariyah \\ Industrial Engineering Department, Universitas Langlang Buana
}

Sustariyah64@gmail.com

\begin{abstract}
The Government appointed Social Health Insurance Administering Body or BPJS Kesehatan. Alleged implementation of operational implementation of Social Security Health is still not yet fully understood and perceived benefits and services by the community, Marketing with a system of proximity to customers and provision of quality services to be one strategy that is effective in improving public confidence. Relational marketing and service quality is a determinant factor in increasing value and trust for customers. The purpose of this study is to analyze the influence of relational marketing and service quality to customer value and its impact on customer trust. The method used is quantitative with expert judgment. The sample of this research is inpatient of BPJS health participant at Public Hospital owned by Local Government in West Java Province. Technique of data retrieval is done by cluster proportional random sampling and analysis technique used is SEM analysis (structural equation modeling). The results of descriptive research indicate that relational marketing, service quality, customer value and customer trust move from less good to sanga tbaik. The results of the study of each indicator is still found some less than optimal. The result of verifikatif research proves that relational marketing and service quality have positive and significant effect to customer value and customer value have positive and significant influence to customer trust.
\end{abstract}

\section{Keywords: Health Service, Acceptance Value, Patient Reliance}

\section{Introduction}

The right to life for the health and wellbeing of a person and his family is a basic human right and is recognized by all nations of the world, including Indonesia. The recognition is contained in the 1948 United Nations Declaration on Human Rights. Article 25 Paragraph (1) of the Declaration states that everyone is entitled to an adequate standard of living for the health and well-being of himself and his family including the right to food, clothing, housing and health care and the necessary social services and is entitled to security in the event of unemployment, illness, disabled, widowed / widowed, reaching old age or other circumstances resulting in a lack of income, which is beyond his power. Data from Universal Health Coverage states that after World War II some countries took the initiative to develop social security, including health insurance for all population (Universal Health Coverage, 2014).
The philosophy and foundation of the Indonesian state is Pancasila. The 5th Precept in Pancasila recognizes citizen's right to health. This right is also contained in the 1945 Constitution article $28 \mathrm{H}$ and Article 34, and regulated in Law no. 23/1992 which was subsequently replaced by Law 36/2009 on Health. In Law 36/2009 it is affirmed that everyone has equal rights in obtaining access to health resources and obtaining safe, quality, and affordable health services. On the other hand, everyone also has the obligation to participate in the social health insurance program. To realize the above global commitments and the constitution, the government is responsible for the implementation of public health insurance through the National Health Insurance (JKN) for individual health.

Health insurance which has been pioneered by the government by organizing some form of social security in the health sector, such as through PT 
Askes (Persero) and PT Jamsostek (Persero) serving, among others, civil servants, recipients of pensions, veterans and private employees. For the poor and the poor, the government provides guarantees through the Public Health Insurance scheme (Jamkesmas) and the Regional Health Insurance (Jamkesda). However, these schemes are still fragmented, fragmented. Healthcare costs and service quality became difficult to control. To address this, in 2004, Law No. 40 on the National Social Security System (SJSN) was issued. Law 40/2004 mandates that social security is compulsory for all residents including National Health Insurance (JKN) through a Social Security Administering Agency (BPJS Kesehatan).

Travel program BPJS Health organized by the government in its implementation is not yet fully optimal. The problems that arise in the community is the level of public understanding of the BPJS Health program implemented by the government. According to Marzuki Alie (2013) in his statement states that Potential BPJS Health program problem is related to public confidence in health services held by the government. The reason, in the health insurance program that has been held by the government, participants are still charged for certain types of drugs. In fact, the drug is not included in the list of Health Insurance programs or just additional drugs offered by doctors who treat participants. Meanwhile, according to Susetiawan (2014) states that the government must implement the Act of Social Security Administering Agency No. 1 of 2014 in a transparent and accountable, because if it is not executed, it is feared there will be a lack of public attention to the government, so the community is no longer attention to the program BPJS Health organized by the government. Therefore, in order to increase public attention to BPJS Health program, the government must be able to provide services in accordance with expectations, so that people feel satisfied with what is obtained from the program that will ultimately form a positive impression and have the awareness to refer to family, friends, colleagues or other parties who need information.

The government is currently aware that the socialization of BPJS Health programs implemented by the government is still not optimal. This is acknowledged by the Chairman of the West Java Provincial Legislative Commission, that the socialization of BPJS Health is still very low, and the result is that many people do not understand the procedures and processes of BPJS Health. Further Chairman of West Java Provincial Legislative Commission stated that there are still many reports of people who do not know the purpose and benefits of BPJS Health program (FokusJabar.com, 2014). The above fact reminds the government to immediately take, marketing strategy step for BPJS Health program useful, so as to give confidence to the public about the truth and seriousness of service programs offered by the Government to the public.

The following factors contribute to the formation of trust (Peppers and Rogers in Fadilah, et.al, 2012), ie values, dependence on the other, open and orderly communication, and behave opportunistically. While Shamdasani and Balakrishan in Gondasamy (2006) states that trust is shaped by the attitude of service provider integrity, reliability, contact personnel and phsyical environment. From this opinion it is clear that trust is a very important factor in marketing activities for both product, service and social marketing in order to increase the quantity of product or service usage.

Customer trust is made up of value received by consumers (Peppers and Rogers in Fadilah, et.al, 2012; Palmatter, 2008 and Hasan, Kiong and Ainuddin, 2014). Customer value is related to trust (Rasheed and Abadi, 2014; Hasan, Kiong 
and Ainuddin, 2014 and Kamtarin, 2012). A series of problems in health service BPJS system, this should be the attention and focus of government in improving the service system, whether it is the service in the field of patient administration and in the field of examination and patient care. The health care system can be built in various ways and methods that can be implemented by the government, such as improving the system, network and service capacity, partnering with private hospitals, so that in the end can provide added value for the community as a participant BPJS Health.

The low socialization delivered to the community has an impact on the low level of public knowledge of the program, so that it will affect the total number of BPJS Health program membership. In the West Java Province itself BPJS Kesehatanbaru participants reached $43 \%$ or as many as 18.8 million people from the total population in West Java Province. According to Nurhandoko $(08 / 05 / 2014)$ stated that only $43 \%$ of West Java residents become BPJS Kesehatan participants as many as 19,993,785 West Java residents are listed as participants of the Social Security Administering Body Health of the total population of 46,497,175 Souls. From the data it is known that $57 \%$ or as many as 26,503,390 people who have not followed the BPJS Health program.

\section{Theoritical Framework}

Management is closely related to the organization as a container or place of management that will play an active role. Organizations without good management will result in organizational routines can not last long. To be more clear, in this case some definitions become starting points in the following descriptions: Organizations are a consciously coordinated, two or more continuous, conscious social unit in order to achieve one or a set of common goals (Robbins and Judge, 2008). Organization is a container formed to achieve common goals effectively (Wibowo, 2007). According to Mary Parker Follet cited by Handoko (2008) management is the art of completing the work through others. This definition implies that managers achieve organizational goals through the arrangement of others to carry out the various tasks that may be required.

The concept of marketing is a business philosophy that says acceptance of values is the foundation of the social and economic truths of a company's life. It is only natural that all activities of the company should be devoted to knowing what the customer wants and then satisfying those desires. Kotler and Armstrong (2012), "Marketing as the process by which companies create value for customers and build strong customer relationships in order to capture value from customers in return". Kotler and Keller (2012) are: "Marketing is the activity, set of institutions, and processes for creating, communicating, delivering, and exchanging offerings that have value customers, clients, partners, and society at large". Based on the above definition, it can be deduced that the meaning of marketing includes an individual or group effort / company to meet its needs by creating, marketing, promoting and delivering goods and services to customers and other companies. So, marketing activities are all activities related to the market, that is to realize possible exchanges.

The service industry is now a very large and growing sector of the economy. This growth is in addition to the growth of preexisting services, also due to the emergence of new types of services, as a result of the demands and technological developments. Viewed from the context of globalization, the rapid growth of service business between countries is marked by the increasing intensity of cross-country marketing as well as the alliance of various service providers in the world. 
These developments are ultimately able to provide strong pressure on regulatory overhaul, particularly the relaxation of protection and utilization of new technologies that will directly affect the strengthening of competition in the industry (Lovelock in Hurriyati, 2008).

This condition directly exposes the business to the increasingly high business competition issues. They are required to be able to identify the forms of competition to be faced, to set various standards of performance and to recognize their competitors well (Grant and Smith, in Ratih Hurriyati 2008). Marketing focuses on the dynamic interrelationships between the company's products and services, the desires and needs of its customers and the activities of its competitors. The marketing function (Payne in Ratih Hurriyati, 2008) consists of 3 (three) key components, as follows:

1. Marketing mix (marketing mix), which is an important internal elements that form an organization's marketing program.

2. Market forces, which are external opportunities and threats that an organization's marketing operations interact with.

3. The process of alignment, namely the strategic and managerial processes to ensure that the marketing mix of services and internal policies of the organization is feasible to deal with market forces.

Understanding marketing is often confused with sales. Though the two concepts are different. Sales depart from products that have been created, then attempted to be sold to customers. While marketing departs from the needs and desires of customers, then newly created or developed products that can meet customer needs. In addition there are equating the notion of marketing with advertising or mass media. This is not true because advertising or the use of mass media is only one element of marketing (MOH, 2007). Marketing itself is a social and managerial process whereby individuals and groups get their needs and wants by creating, offering, and exchanging something of value to each other (Kotler and Keller, 2012). Kotler and Keller (2012) explains that social marketing is a strategy for changing behavior. Social marketing combines elements of a traditional approach to social change within an integral framework of action and planning and uses the skills of communication technology and marketing skills.

Social marketing is basically no different from commercial marketing, social marketing uses the same analytical techniques (market research, product development, pricing, affordability, advertising and promotion). Thus it can be concluded that social marketing is the application of marketing concepts and techniques to obtain social benefits. Of course there is little difference between commercial marketing and social marketing. Differences between commercial marketing and social marketing according to the MOH (2007) include: 1) the use of social products is usually more complicated than commercial products, eg the use of oralit is not as easy as drinking coca-cola, 2) social products are often controversial, 3) social products are not quickly perceived, 4) distribution channels for social products are more difficult to control because they usually involve multiple parties, 5) customers are generally incapacitated, vulnerable to illness and poorly educated.

Social marketing in international health programs plays a role in commodity sales and ideas or behaviors. In fact social marketing almost always starts with a promotion of health-related attitudes or beliefs. Based on that suggested the new product or service, and given instructions on how to use effectively. Social marketing is basically customer-oriented. The customer or the user is not only a 
fundamental goal, but also as a measure of whether the activities carried out are suitable, desirable and successful. Customers are systematically consulted throughout the social marketing process, providing data for decisive marketing decisions (MOH, 2007). In the marketing process in society, various things can influence customers to determine and choose a goods / services. Where each element will be able to provide opportunities, strengths and threats to the company (Herry and Saladin, 2010). Each element is:

1. Population, such as age, family status, education and income.

2. Economy, that is directed to the per capita income of society that determines the power of purchasing power (purchasing power).

3. Physical environment, ie relating to the use or utilization of natural resources.

4. Technology environment, which is related to the growth rate of existing technology in the company.

5. Politics, which is related to the policies undertaken and stipulated by the government.

6. Social culture that is related to the characteristics of customers to determine opportunities and threats in the form of customs and habits of society.

$\begin{array}{lrr}\text { Understanding } & \text { Customer } & \text { Relationship } \\ \text { Management } & \text { (CRM) } & \text { Customer }\end{array}$ relationship management or customer relationship management (hereinafter abbreviated as CRM) is a concept that varies according to the views of various parties. Even the meaning of CRM stands it has been varied and disputed for a long time. For some, CRM stands for customer relationship marketing. Meanwhile, the group believes that not all customers want a supplier relationship, remove the word "relationship", and choose a shorter term, "customer management" or "customer management". There are also parties who prefer the term "relationship marketing". Whatever the obvious term CRM is a focused or customer-oriented business practice (Buttle, 2007).

As companies continue to seek new ways to win competitively in order to improve performance, recent research shows that Customer Value Management (CVM) is a value approach. CVM can improve business performance in three ways: (1) CVM is a market-based resource for competitive advantage, (2) CVM improves customer-centric corporate orientation, and (3) CVM leads to more accountable marketing (see Figure 2.1). CVM provides companies with sustainable competitive advantage.

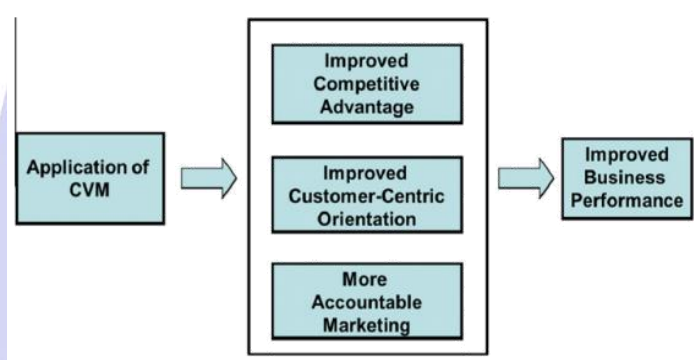

Figure 2.1 Mechanisms through CVM Improve Business Performance

Source: Verhoef and Lemon (2013)

The customer base data in the company and the customer network is an important resource based on the market because in obtaining new customers is relatively difficult to develop. Research shows that databases containing customer acquisition and retention are data bases in order to improve business performance. In addition, research shows that the formal system for identifying and managing customers is highly potential in higher-performing firms (Becker, Greve \& Albers, 2009; Jayachandran, Sharma, Kaufman, \& Raman, in Alshourah, 2012; Reinartz, Krafft \& Hoyer, 2009).

CVM creates a stronger focus on customers because through a customercentric approach. In addition, CVM provides companies with extensive customer knowledge. Extensive Research shows that companies with 
customer-oriented or customer-centric tend to have a stronger performance than the company without creating the CVM. CVM is a leading sector to be able to analyze and as a basis in making decisions to increase investment in marketing, this is because CVM is the result of customer analysis. Relational Marketing (Relationship Marketing) is a philosophy of running a business that focuses primarily on improving service to existing customers compared to finding new customers. From this definition it can be said that Relationship Marketing is an effort to get to know the customer better, so the company can meet their needs and wants in the long term (Zeithmal et al., 2012).

The above definition is supported by the opinion of Arafat in Semadi, et.al. (2012: 161) who argued that establishing relationships with customers in the long run does not just create transactions. Being a new paradigm for achieving marketing success is by establishing and maintaining customer relationships on an ongoing basis. The paradigm is called relationship marketing.

The customers in making a purchase will take into account the offer that will give the highest score. They want maximum value, limited by search costs and limited knowledge, mobility, and income, they form an expectation of value and act accordingly. Customers are the central point of business, have bargaining power, and are now educated and informed than ever. In the increasingly fierce competition and development of the globalization era, marketing managers must continue to strive to develop a customer-oriented culture culture. This culture is aimed at winning the hearts of customers and maintaining their loyalty by creating and delivering value to customers who outperform competitors. Herry Achmad Buchory \& Djaslim Saladin (2010: 66). Wykof quoted from Tjiptono (2008: 59) states that: Quality of service is the expected level of excellence and control over the level of excellence to meet customer desires. The concept of customer value (customer value) provides an overview of a company's customers who consider what they want and believe that they benefit from a product they get (Lapierre in Wibowo, 2013). This indicates that the quality of service must be able to provide high value to the customer, the value is the expected benefits (Kotler and Keller, 2012).

Thus it can be said that the quality of service affects the value of customers, this is supported by research conducted Chen (2010) who found the fact that the quality of services have a positive effect on customer value, these results are supported Wan-I lee, Tsung-Hao Chen and Chen-Yuan Chen (2010) who found the fact service quality has a positive effect on customer value. Cronin and Brady in Lee et.al (2010) confirmed in his research, also proposed their research on how customer orientation influences customer's perceived service quality and behavior intention, which indicates that, customer orientation influences customer's perceived service quality directly and service quality influences customer value positively.

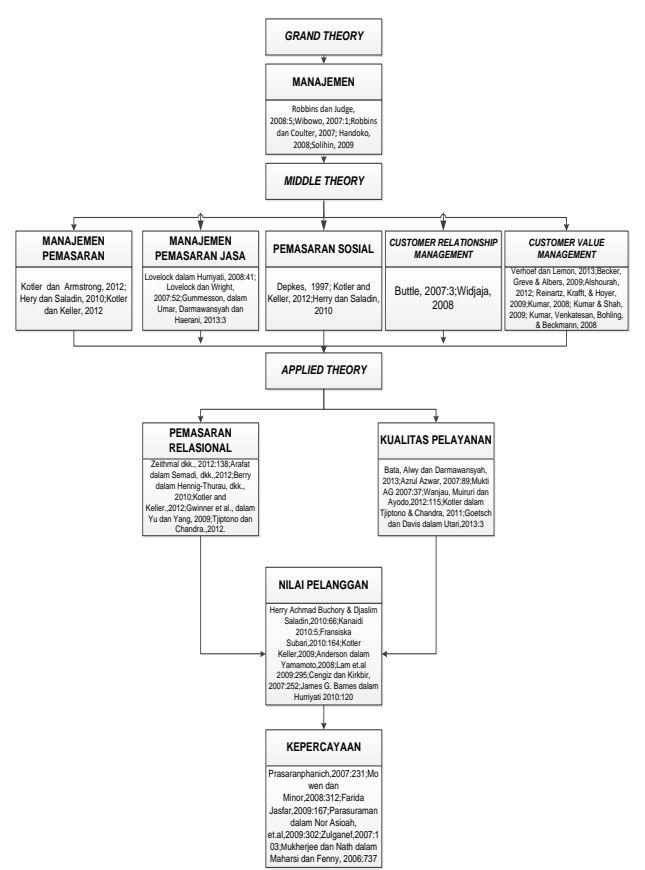

Figure 2.2 The Research Theory 


\section{Methodology}

This research is included in descriptive and verifikatif analysis with emphasis on exploration and interpretation of research results that have the purpose to analyze the presence or absence of influence between the relational marketing variables and the quality of health services to the acceptance of value and the impact of patient confidence BPJS health participants. Therefore, in the implementation of this research used two research methods namely, namely descriptive and verifikatif. Verifikatif research is a type of research that aims to determine the relationship between variables through a hypothesis testing. Descriptive research aims to obtain a description of the characteristics of variables seen from frequency distribution, percentage, mean value and standard deviation to solve problem formulas 1-4. While verifikatif research to see the influence between variable constructs and hypothesis testing to complete the formulation 5-8. The place of research is at the Hospital of patients receiving BPJS health in Bandung regency. While the subject of the study is the patient BPJS health participants for both outpatient and outpatient. The determination of the location of this study is based on the Regulation of the Social Security Administering Body Number 1 of 2014 on the Implementation of Health Insurance.

This study aims to examine the influence of relational marketing and the quality of health services on the acceptance of value that affects the confidence of patients participating BPJS Health. Based on the grouping, this research includes explanatory research because this research intends to explain the causal relationship between variables through hypothesis testing. In designing descriptive-verification research design, the following steps are taken:

1. Conduct a preliminary study. This step is taken in order to explore the current phenomenon related to the object of research. The tools used in conducting preliminary studies include interviewing, observation, documentation studies, theoretical studies known as preliminary research, so that the results will get a definite picture of the phenomenon.

2. Identify problem and problem formulation. This step is taken as an indication of the phenomenon of research, then the title can be set to be studied. In this study the problems that occur focused on the confidence of patients participating BPJS health.

3. Setting a frame of mind. This step is taken in the framework of making the research flow, the relationship of variables in concept and theory, and identification of the literature review that gave birth to the grand theory, middle theory and application theory. In addition, birth also paradigm of research in konspetual which sourced from problem formulation and research hypothesis.

4. Setting research hypotheses, based on phenomena and theoretical support.

5. The concept of variable as well as measurement of research variables used.

6. Establish an instrument. Instrument as a research tool in the framework of collecting data in the form of questionnaires. Prior to data analysis, the instrument is tested the validity, reliablitas and normality of data.

7. Conduct data analysis. Data analysis in this research using inferential statistical analysis method. Descriptive and Verifikatif Method.

8. Conclusions. Conclusion is the answer of the formulation of the problem raised from the research hypothesis. 


\section{Result and Discussion}

On October 19, 2004, the Government issued Law no. 40 of 2004 on the National Social Security System (SJSN). SJSN according to Article 1 number 2 of Law Number 40 Year 2004 is a regulation of social security program implementation by several Social Security Administering Board (BPJS). In the National Social Security System, there are 5 (five) types of social security programs that will be held by the Government, namely:

1. Health Insurance Program

2. Work Accident Guarantee Program

3. Old Age Guarantee Program

4. Pension Plan Program

5. Death Guarantee Program

Article 58 of the BPJS Law states that the Board of Commissioners and the Board of Directors of PT Askes (Persero) is assigned to prepare the operational BPJS Kesehatan health insurance program in accordance with the provisions in the SJSN Law and to prepare the transfer of PT Askes (Persero) assets and liabilities, BPJS Health. Associated with the assignment of PT Askes (Persero) to become BPJS Health, a strategic plan for the transition period of 2012-2013, which for 2013 is focused is the transformation of PT Askes (Persero) into BPJS Health, with a vision built. PT Askes ( Persero) transformed into BPJS Health which has operated effectively starting January 1, 2014.

\subsection{Analysis of Respondent's Characteristics}

Analysis of respondent characteristics in this study consisted of respondent age, sex, last education, occupation, income and health BPJS membership described as follows:

Table 4.1 Age of Respondents

\begin{tabular}{llcc} 
No & \multicolumn{1}{c}{ Age } & F & $(\boldsymbol{\%})$ \\
\hline 1 & $<20$ thn & 31 & 7.848 \\
\hline 2 & $20-30$ thn & 48 & 12.152
\end{tabular}

\begin{tabular}{llll}
3 & $31-40$ thn & 112 & 28.354 \\
\hline 4 & $41-50 \mathrm{thn}$ & 72 & 18.228 \\
\hline 5 & $>50 \mathrm{thn}$ & 132 & 33.418 \\
\hline \multicolumn{2}{l}{ Total } & 395 & 100.000 \\
\hline $\begin{array}{l}\text { Source: } \\
\text { processed, 2015 }\end{array}$
\end{tabular}

Table 4.1 above shows that most of the respondent age is above 50 years ie 132 people or $33,418 \%$. Age of respondents between 31 - 40 years of 112 people or $28.354 \%$. Age of respondents between 41 - 50 years as many as 72 people or 18 , $228 \%$. Age of respondents between 2030 years as many as 48 respondents or $12.152 \%$ and age of respondents less than 20 years as many as 31 people or by $7,828 \%$. The conclusion of the analysis indicates that the data of BPJS health participants in West Java Province General Hospital is dominated by elderly people who are above 50 years old.

Table 4.2 Gender Respondents

\begin{tabular}{clcc} 
No & Gender & F & (\%) \\
\hline 1 & Man & 223 & 56.456 \\
\hline 2 & Woman & 172 & 43.544 \\
\hline Total & 395 & 100.000 \\
\hline $\begin{array}{l}\text { Source: } \\
\text { processed, } 2015\end{array}$ & Respondent & stuffing data & data
\end{tabular}

Table 4.2 shows that most of respondent's gender is male as much 223 persons or $56,456 \%$ and some female are 172 persons or $43,544 \%$. The conclusions of the analysis indicate that the participant data of inpatients of BPJS participant of health is dominated by men.

Table 4.3 Respondents Education Level

\begin{tabular}{|c|c|c|c|}
\hline No & Education & $\mathbf{F}$ & $(\%)$ \\
\hline 1 & SD & 77 & 19.494 \\
\hline 2 & SMP & 92 & 23.291 \\
\hline 3 & SMA & 133 & 33.671 \\
\hline 4 & Diploma & 52 & 13.165 \\
\hline 5 & Sarjana & 29 & 7.342 \\
\hline 6 & Pascasarjana & 12 & 3.038 \\
\hline & Total & 395 & 100.000 \\
\hline
\end{tabular}
processed, 2015 
Based on Table 4.3, it can be seen that most respondents have high school education level of 133 people or $33.671 \%$. Education level of junior as much 92 people or $23,291 \%$, education level of elementary school counted 77 person or $19,494 \%$, level of Diploma education as much 52 people or $13,165 \%$, level of education of Bachelor counted 29 people or equal to $7,342 \%$ and level of education Graduate as much 12 people or $3,038 \%$. Furthermore, the analysis of other respondent characteristics about BPJS health income and participation can be described as follows:

Table 4.4 Respondents' Revenue Rate

\begin{tabular}{|c|c|c|c|}
\hline No & Fee & $\mathbf{F}$ & $(\%)$ \\
\hline 1 & < IDR 1.500.000,- & 35 & 8.861 \\
\hline 2 & $\begin{array}{c}\text { IDR } 1.500 .000,- \\
\text { Until } \\
\text { IDR } 2.500 .000,-\end{array}$ & 167 & 42.278 \\
\hline 3 & $\begin{array}{c}\text { IDR } 2.600 .000,- \\
\text { Until } \\
\text { IDR } 3.000 .000,-\end{array}$ & 118 & 29.873 \\
\hline 4 & $\begin{array}{l}\text { IDR } 3.100 .000,- \\
\text { Until } \\
\text { IDR } 4.000 .000,-\end{array}$ & 46 & 11.646 \\
\hline 5 & > IDR 4.100.000,- & 29 & 7.342 \\
\hline & Total & 395 & 100.000 \\
\hline
\end{tabular}

Source: Respondent stuffing data processed, 2015

Based on Table 4.4, it can be seen that most respondents have income level between Rp1, 5 million - Rp2, 5 million as much as 167 people or by $42.27 \%$. Other respondents who earned between 2.6 million to $\mathrm{Rp} 3$ million were 118 people or $29.873 \%$. The income level between 3.1 million to 4 million is 46 people or $11.646 \%$, the income level is more than Rp. 4.1 million as many as 29 people or by $7.342 \%$ and income level less than Rp.1, 5 million as many as 35 people or $8.861 \%$. The conclusion of the analysis shows that some BPJS health participants in West Java Province have income between $\mathrm{Rp} 1.5$ million to $\mathrm{Rp} 2.5$ million.

The results of research on the quality of service descriptively moving from start quite well up to very baik.Kualitas service in this study emphasizes the physical aspects, reliability, responsiveness, assurance and empathy described to 23 indicators have been largely perceptible pretty well up to very well. The highest assessment of the results of service quality analysis amounted to $70.617 \%$ and the results of the lowest valuation of $29.459 \%$. These results indicate that the quality of service has been implemented fairly well to the community of $70.617 \%$, but still there are about $29.459 \%$ need to be done improvements in the implementation of quality services.

The research findings reveal data and the fact that the completeness of the physical facilities owned, the hospital response in prioritizing patients participating BPJS, completeness of medicines owned by the Hospital and incompatibility between services provided less appropriate expectations. The low findings as a result of the limited health budget sourced from the state budget funds, although there is an increase from year to year, but in reality is still below expectations. In addition, sometimes the Hospital does not always prioritize patients participating BPJS health and more prioritize other general patients who direct payment system, limited human resources owned by the Regional General Hospital when compared with the number of patients.

From the results of interviews with judgment ekpert, obtained the proposal that:

1. The community must be a participant BPJS, but the level of public understanding of the BPJS program is still low, so it needs to be done relational Marketing application which aims to give the community a sense of the importance of participation BPJS program.

2. BPJS Health Manager is the government, with the division of tasks BPJS as manager of management and administration, 
while the hospital is the manager of health activities technically, so it needs to be synchronized in the implementation simultaneously.

3. Given Facilities and physical infrastructure is still very limited, not balanced with the number of residents who are required to follow the Program BPJS

Based on the result of descriptive analysis and verifikatif analysis from Influence of Relational Marketing and Quality of Health Service to Value Admission and its Impact on Trust (Survey on Patient Inpatient of BPJS Health Participant in General Hospital of West Java Province) hence further researcher need to do more discussion about condition and phenomena related to the above-mentioned variables and which are useful for increasing trust. This discussion will also explain comprehensively about the relationship between independent variables and the magnitude of the path coefficient of independent variables to the dependent variable and the magnitude of the influence directly or indirectly of each variable.

\section{Conclusion}

Based on the results of the study, the discussion and interpretation described in the previous chapters, with reference to several theories and the results of previous research, can be drawn the following conclusions:

1. On Relational Marketing, the BPJS health program has been implemented by the government accountably and seriously, but the government's commitment in providing convenience to all BPJS health patients, is still not in line with expectations, especially in response to community claims. This is in accordance with the judgment expert, that the government has tried maximally in handling BPJS program, but since the program is still new, while the number of participants is not yet equal to the number of available medical staff, the government has not fully fulfilled the public expectation.

2. The implementation of the government through RSUD has provided quality services supported by the ability of the hospital in providing care and standardization services provided by nurses, doctors and administrative personnel. Nevertheless, people still feel that the physical facilities, completeness of medicines owned by hospitals are still not in line with expectations. In Experts Judment mentioned that the physical facilities for BPJS participants, funded from the source BPJS membership, by means of cross subsidy, however, since BPJS just started from January 1, 2014, then the government still must gradually in the allocation of drug and building financing.

3. The added value received by BPJS health participants is the hospital's readiness in accepting patient BPJS health participants and government consistency in running BPJS health program. However, people are still complaining about BPJS health program reliability, people still feel the mismatch between BPJS health programs submitted with its implementation, especially in providing more value in the administration of administrative ease and work ethics of administrative personnel who are still not in accordance with patient expectations.

4. In the opinion of the Expert Judment, the number of medice and non-medical personnel available to serve BPJS health participants has not been fully met, so there is a lack of service.

5. Community trust on BPJS program is supported by the quality of Regional General Hospital which experienced the development and availability of treatment room in 
accordance with predetermined standards. But people still do not believe in the consistency of BPJS health programs and facilities received by BPJS health patients.

6. Relational marketing and service quality have positive and significant influence simultaneously to customer value.

7. Relational marketing has a positive and significant impact on customer value.

8. Quality of service has a positive and significant impact on customer value.

9. Customer value positively and significantly affects customer trust

Based on the conclusions of the above research, can be put forward suggestions that need to be followed up, both for the development of knowledge, for further researchers especially interested in the field of Marketing Management, as well as practical interests.

1. Improve the socialization system of the BPJS program to the community, since the BPJS program is still classified as a new policy program by the government and to increase the government's commitment in providing convenience and closeness with the community towards the health BPJS program through: a. Construction of new registration booth area with more counters b. Open the online registration system c. Open contact center and sms hotline d. Creating a continuously fixed queuing system to speed up the queue e. Building a new centralized outpatient building so that patients are more comfortable f. Simplification of CT scan verification path, MRI, and nuclear inspection g. Simplifying the flow of nuclear medicine services $h$. Create an integrated Diagnostic Center so that patients do not have to walk far / around for the diagnosis of the disease, and others.

2. Improve BPJS patient health service system by increasing budgeting for health sector especially to equip facilities and infrastructure and enlarge capacity of District General Hospital which still have limitations in quantity of care. These improvements can be done through the repair of buildings such as registration booth, medical record room, cardiac center, new medical check up room, and so on. Increased competence of doctors who serve patients should be in accordance with the needs of the community, which can be done through the education of a physician specialist.

3. The organizers of BPJS health need to conduct monitoring and evaluation on the implementation of BPJS program considering technical and non-technical problems, which can be done through the addition of customer care unit for patients, call center for BPJS patient and queuing system improvement so patients can add value to customers.

4. Increased confidence in patients can be done through arrangements to fit the rules of quality control and cost control, so that this can provide confidence in patients on the BPJS program. In order for the patient to trust, the organizer must be more transparent in its financing

\section{References}

Atta, Olfat Ebrahem Gadelrab. 2012. The Efficacy of Applying the Quality Measure of Health Service on the External Patient Satisfaction. Pengantar

Administrasi Kesehatan. Jakarta: Bina Rupa. Aksara.

Dalinjong PA and Laar AS. 2012. The national health insurance scheme: perceptions and experiences of health care providers and clients in two district of Ghana. Health Economics Review 2012, 2:13.

Management Review: An International Journal Volume 7 Number 2 Azwar, Azrul. (2007). 
Gunawan, Ketut dan Sundring Pantja Djati.2011. Kualitas Layanan dan Loyalitas Pasien (Studi pada Rumah Sakit Umum Swasta di Kota Singaraja-Bali). Jurnal Manajemen Dan Kewirausahaan, VOL.13, NO. 1, MARET 2011: 32-39

Heatubun Ermina M, Irwandi Kapalawi dan Alimin Maidin. 2012. Studi Kualitas Pelayanan Jamkesda Ditinjau Dari Segi Kepuasan Pasien Di Ruang Rawat Inap
RSUD Daya Makassar Tahun 2012.

Kotler, Philip and Kevin Lane Keller. 2012. Marketing Management. $14^{\text {th }}$ Edition. New Jersey: Prentice Hall.

Nofiana, Hendri dan Sri Sugiarsi.2011. Hubungan Mutu Pelayanan Pendaftaran dengan Kepuasan Pasien Rawat Jalan di Rumah Sakit PKU Muhammadiyah Karanganyar. Jurnal Kesehatan, ISSN.1979-9551, VOL. V. NO.1, MARET 2011, Hal 90-106.

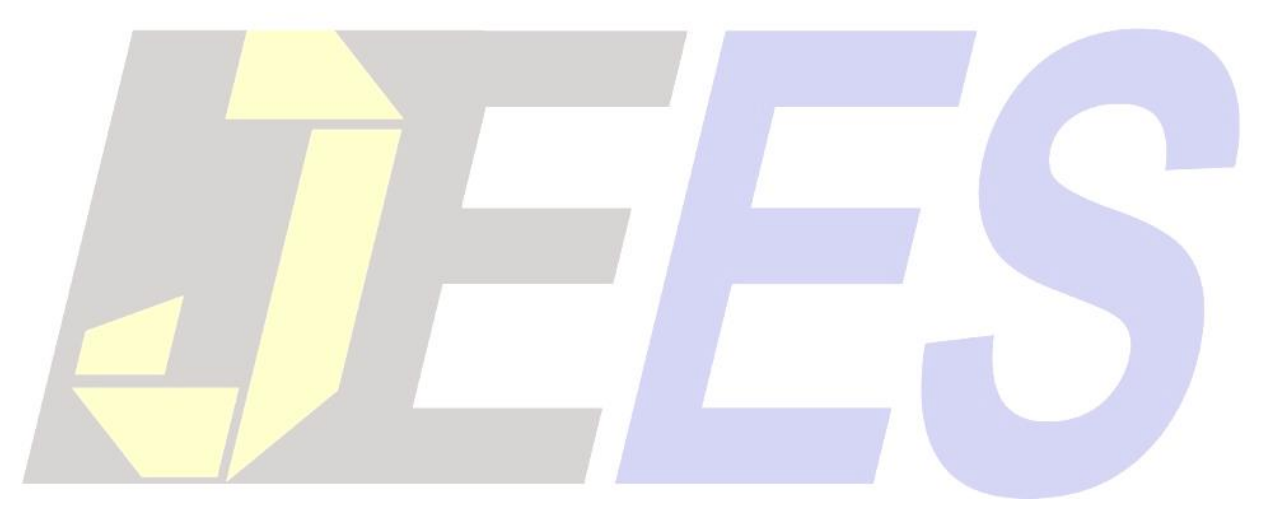

